\title{
COMPARATIVE ANALYSIS OF INCOME DIFFERENTIALS BETWEEN MEN AND WOMEN IN URBAN AND RURAL HOUSEHOLDS IN BAYELSA STATE, NIGERIA
}

\author{
Zechariahs Benapugha Owutuamor, Inibehe George Ukpong
}

\author{
Department of Agricultural Extension and Management, Federal Polytechnic, Ekowe, Bayelsa State, \\ Nigeria \\ *Corresponding author: ilsignorzax@gmail.com
}

Citation: Owutuamor, Z.B., Ukpong, I. G. 2021. Comparative Analysis of Income Differentials between Men and Women in Urban and Rural Households in Bayelsa State, Nigeria. J. Asian Rur. Stud. 5(1): 56-62

\begin{abstract}
This study was carried out across Bayelsa State on the comparative analysis of income differentials between men and women in rural and urban households, to examine the level of income earned by women relative to that of men in rural homes and in urban/semi-urban homes, as well as make a comparative analysis between both. Structured questionnaires were used to collect primary data, using a modified multistage random sampling procedure, from each of 160 rural and urban homes, giving a total of 320 respondents across the eight local government areas (LGAs) in the state. Descriptive statistics, in the form of ranges, averages, totals and percentages were used to analyze data. Findings revealed that women earn an average of $\$ 708,335.00$ in rural homes and $\$ 932,612.87$ in urban homes, while men on the average, earn $\$ 1,234,828.13$ and $\$ 1,406,031.25$ in rural and urban homes respectively. Conclusively, across homes in Bayelsa State, men generally, with an average proportion of about $62 \%$, earn more than women with $38 \%$; Similarly, across the state, men in rural homes earn an average of $63.5 \%$ compared to women who earn $36.5 \%$; while in urban Bayelsa, the proportions are $60 \%$ and $40 \%$ for men and women respectively. Thus, indicating that rural women earn less than urban women in both value and proportion, while rural men earn lower income but higher proportion of the total household income than urban men.
\end{abstract}

Keywords: Household ncome, Rural, Urban, Women, Bayelsa State

\section{Introduction}

Traditionally, men were supposed to earn income for the family, with a view to providing finance for household expenditures. According to Roy et al., (2017), the status of women is domestic in nature, having been considered as a docile daughter, a complacent wife and a dependent mother. But, diminished economic prospects of less-educated men, rising relative wages of women within marriage at all levels of education and the fact that men in the middle of the earnings distribution cannot contribute enough to the household (Lundberg, Pollak, \& Stearns, 2016) have made many women engage in economic activities. Women's participation in economic activities in general has remained low, but recent labor force survey conducted by the Bureau of Statistics showed rapidly increased participation of women in economic activities (Roy et al., 2017). This scenario can be attributed to changing times and attitudes, coupled with increased women education, enlightenment and emancipation drives, that has brought about increased participation of women in civil, economic, political, religious and social activities, thus, bringing about a paradigm shift.

Nonetheless, in many families today, as against what it used to be in times past, both the men and women engage in economic activities to earn incomes, which are sometimes jointly used to finance household expenditures or are apportioned in such a way that each of them 
carries out particular expenditure(s) on certain items from their income. It is also not out of place in some families, where the woman is actually the only income earner or breadwinner, even though there is a capable man in the house, who is not economically engaged due to increasing unemployment in the country. Also, in some families, even where the man earns an income, the woman is engaged in more diversified economic activities, which enables them to earn more than their husbands, thus, making them (the women) bear the brunt of financing the household expenditures, even though such roles have been traditionally regarded as that of the man. Similarly, Oláh, Richter, and Kotowska (2014) stated that the new female gender role has, thus, increasingly incorporated dimensions of economic independence and support responsibilities that until quite recently, belonged to the male domain, and promoted a more equal distribution of responsibilities for the economic provision to a family. This assertion found support in the fact the UN Women (2019) reported that evidence for the United States and other high income countries suggests that as people with similar socio-economic backgrounds form unions, greater income inequality may set in.

Earlier reports by the International Labour Office (2004) suggested that one of the most striking phenomena of recent times, has been the increasing proportion of women in the labour force, enabling women in many regions to use their potential in the labour market to achieve economic independence. Despite the fact that women's participation in the labour market is increasing, it does not really mean that the gap between male and female participation is closing and also that both men and women favor the same kind of occupation. In recent times, the International Labour Office (2018) reported that the past 20 years have witnessed some progress for women in the world of work and in terms of gender equality in society. Today, more women than ever before are both educated and participating in the labour market, thus, reducing poverty and boosting economic development. Yet, despite the progress made, coupled with the global commitments to secure further improvement, women's prospects in the world of work are far from being equal to that of men. Similarly, reports by Law (2020) indicated that women in the United States of America (USA) are now the majority in the workforce for the first time in a decade, holding up to $50.04 \%$ of American jobs. This has given them increased economic powers in the households, yet economists are of the opinion that societal and workplace forces, such as being employed with low pay and the childcare conundrum, still hold women down.

In Nigeria, the World Bank (2019) reported that $45.5 \%$ of the Nigerian labour force is populated by women. Olowa and Adeoti (2014) and Enfield (2019) posited that this percentage shows that women's participation in formal and informal labour markets is on a positive trajectory and has been rising in both rural and urban areas through the period 19902009 but remains lower than that of males. However, results obtained by Gayawan and Adebayo (2015), in establishing the fact that huge geographical variation exists in the rate of women's involvement in the labour force in Nigeria, suggested that place of residence do not indicate difference in the likelihood of engaging in all-year round jobs between women who dwell in rural areas and those in urban areas. Furthermore, Owutuamor, Owutuamor and Ukpong (2020) reported that in Ekeremor Local Government Area of Bayelsa State, even though, most of the women are married to husbands that earn income, they (women) also earn their own income and contribute to the household financially. Similarly, Owutuamor, Fems and Owutuamor (2020) also reported that a good proportion of women in Southern Ijaw LGA of Bayelsa State engage in productive activities and earn income from them, with some also having secondary occupations from which they earn more income, even though they have spouses that work.The foregoing, thus, suggests that more women are taking part in economic activities to augment for what the men provide or did not provide in terms of 
financing household expenditures, thereby bringing about the need to find out if such scenarios also exist in low income or developing countries like Nigeria, especially in Bayelsa State. The case for Bayelsa State might be different based on the fact that the State has most of its urban areas in the upland areas, while the rural areas are in the creeks. As such, it is necessary to carry out studies, whose findings would either support the foregoing or provide a new insight to the situation existing in Bayelsa State, due to its peculiar terrain, which of course would determine the kind of occupation people are engaged in.

This study which has many implications, helps contribute knowledge to ongoing debates about the types of occupation men and women engage in, be it in the rural or urban areas. It also helps generate a database for a better understanding of women and men's employment in the rural or urban areas of our society, that will serve as basis for more gender based economic researches, in a bid to help advance the push for sustainable development. Being a comparative study, it may provide a clear picture of the kind of employment mostly engaged in by men and women, in the rural areas against those in the urban areas. Similarly, income levels for both men and women in the rural areas were compared to those of men and women engaged in economic activities across the urban areas of Bayelsa State.

The broad objective of this study is to carry out a comparative analysis of income differentials between men and women in urban and rural households in Bayelsa State of Nigeria, while the specific objectives are to: (i) comparatively determine the kind of occupations engaged in by both men and women, in the rural and urban areas; (ii) ascertain the level of income earned by women relative to that of men in rural households; (iii) determine the level of income earned by women relative to that of men in urban/semi-urban households; and (iv) make a comparative analysis between what obtains in the rural areas and that of the urban areas.

\section{Methodology}

The study was conducted in Bayelsa State of Nigeria. The State, according to the 2006 National Census has a population of 1,704,515 people (874,083 females and 830,432 males), covers an approximate land area of 9,415.8 $\mathrm{KM}^{2}$ and eight (8) local government areas (LGAs), (Bayelsa State Government, 2018). The State which has mangrove forests and brackish water, with lots of fresh water creeks meandering southwards to the Atlantic Ocean, falls within the tropical rainforest belt (Owutuamor, Owutuamor \& Ukpong, 2020). The major occupation of the residents are fishing, farming, boat building, water transportation, lumbering, trading, civil service, palm wine tapping and local gin distillation (Owutuamor, 2018; Owutuamor, Fems \& Owutuamor, 2020).

Primary data collected via the use of structured questionnaire were used for the study. A total sample of 320 households was taken in a modified multistage random sampling technique, 160 respondents were each sampled in rural and urban/semi-urban areas respectively. The first stage involved selecting two (2) rural communities and two (2) urban communities from each of the eight (8) LGAs, making a total of four (4) towns for each LGA. In the second stage, 10 households were randomly sampled. The types of occupation the respondents do, were categorized into three (3) major groups, viz: (i) Working for private organizations or being employed by other people; (ii) Working for the Government or its agencies; and (iii) Being self-employed or entrepreneurial. 
Data was analyzed using descriptive statistics. Frequency counts and percentages were used to determine the proportions of people engaged in different types of occupation. Range was used to calculate the difference between the lowest annual incomes earned ( $N 0.00)$ and the highest income earned by either the man or woman. Percentages were used to determine proportion of incomes earned, while aggregation and averaging were also done to arrive at the total and mean values respectively. All the results were displayed in tables.

\section{Results and Discussions}

\section{Types of occupation respondents engage in}

Data collected from the field on types of occupation respondents in households engaged in, based on gender, were analyzed and presented in Table 1. In this study, the types of occupations were categorized into being: (i) employed by private organizations or other people; (ii) the Government or its agencies; and (iii) self-employed or entrepreneurship. From Table 1, results reveal that both men and women are mostly self-employed, with $44.4 \%$ for men and $48.1 \%$ for women respectively in the rural areas in Bayelsa State. However, the results also show that a higher percentage of women are more self-employed than men. Similarly, the proportion of women that are unemployed $(21.3 \%)$ is also higher than that of men (8.1\%) in rural Bayelsa. This is in contrast to reports by the OECD (2016), which asserted that in OECD economies, one in ten employed women is self-employed and that almost half the rate of self-employed men $(18 \%)$, but, during the past ten years, however, the gap between male and female self-employment rates has closed in almost every country.

Table 1: Distribution of respondents based on type of occupation

\begin{tabular}{|c|c|c|c|c|}
\hline $\mathbf{S} / \mathbf{N}$ & Sex & Type of Occupation & Frequency & Percentage \\
\hline \multicolumn{5}{|c|}{ Rural Areas } \\
\hline \multirow[t]{5}{*}{1.} & Men & Unemployed & 13 & 8.1 \\
\hline & & Work for Private Organizations & 54 & 33.8 \\
\hline & & Work for Government & 22 & 13.8 \\
\hline & & Self Employed & 71 & 44.4 \\
\hline & & Total & 160 & 100.0 \\
\hline \multirow[t]{5}{*}{2.} & Women & Unemployed & 34 & 21.3 \\
\hline & & Work for Private Organizations & 35 & 21.9 \\
\hline & & Work for Government & 14 & 8.8 \\
\hline & & Self Employed & 77 & 48.1 \\
\hline & & Total & 160 & 100.0 \\
\hline \multicolumn{5}{|c|}{ Urban Areas } \\
\hline \multirow[t]{5}{*}{3.} & Men & Unemployed & 16 & 10.0 \\
\hline & & Work for Private Organizations & 44 & 27.5 \\
\hline & & Work for Government & 29 & 18.1 \\
\hline & & Self Employed & 71 & 44.4 \\
\hline & & Total & 160 & 100.0 \\
\hline \multirow[t]{5}{*}{4.} & Women & Unemployed & 31 & 19.4 \\
\hline & & Work for Private Organizations & 31 & 19.4 \\
\hline & & Work for Government & 16 & 10.0 \\
\hline & & Self Employed & 86 & 53.8 \\
\hline & & Total & 160 & 100.0 \\
\hline
\end{tabular}

Source: Author's computation from field data 
The results, as presented in Table 1, shows that, in the urban areas of Bayelsa State, the trend is similar to that of the rural areas; with self-employed men being $44.4 \%$ and selfemployed women being $53.8 \%$. It can also be observed that the proportion of self-employed women in the urban areas is higher than that of men in the rural areas. Similarly, the proportion of unemployed women $(19.4 \%)$ is higher than that of the men $(10.0 \%)$ in the urban areas of Bayelsa State.

From the foregoing, it is evidently clear that women in Bayelsa State, residing either in rural or urban areas are more engaged in self-employment activities when compared to the men. That is to say that, in Bayelsa State, women generally prefer self-employment to either working for other people, private organizations or even the government. This as explained by Georgellis and Wall (2004), indicates that womens' preference for self employment is an especially important factor given the difference in labour market opportunities and occupational strategies. They further explained that women's preference for self-employment may be because women respond differently than men to earnings differentials between salaried employment and self-employment, as earnings differentials are specifically important for men but not for women. More so that capital constraints impose a major obstacle for men to become self-employed but not for women, or perhaps, women may be particularly attracted to the flexibility and child care advantages that self-employment may offer.

\section{Income distribution in Bayelsa State}

Data collected for income distribution of both men and women respondents in rural and urban households of Bayelsa State are presented in Table 2. The results indicate that women earn less than men in Bayelsa State, be it in the rural or urban area, averaging about $38 \%$ of the total household income across the state. That means that men in Bayelsa State earn almost twice as much income, as the women earn in Bayelsa State. This reflects the British Council Nigeria (2012) report, that there is significant income inequality between men and women in Nigeria, thus reflecting in equal opportunities for earning a living.

Table 2: Income distribution among men and women

\begin{tabular}{lllll}
\hline Income & Maximum (N) & $\begin{array}{l}\text { Total } \\
(\mathbf{N})\end{array}$ & $\begin{array}{l}\text { Mean } \\
(\mathbf{N})\end{array}$ & \% of total \\
\hline Total female income & $17,000,000.00$ & $262,551,660.00$ & $820,473.94$ & 38.3 \\
Total male income & $17,800,000.00$ & $422,537,500.00$ & $1,320,429.69$ & 61.7 \\
Total household income & $17,800,000.00$ & $685,089,160.00$ & $2,140,903.63$ & 100.0 \\
\hline Rural areas & & & & \\
Total female income & $3,650,000.00$ & $113,333,600.00$ & $708,335.00$ & 36.5 \\
Total male income & $11,500,000.00$ & $197,572,500.00$ & $1,234,828.13$ & 63.5 \\
Total household income & $14,620,000.00$ & $310,906,100.00$ & $1,943,163.13$ & 100.0 \\
\hline Urban areas & & & & \\
Total female income & $17,000,000.00$ & $149,218,060.00$ & $932,612.87$ & 39.9 \\
Total male income & $17,800,000.00$ & $224,965,000.00$ & $1,406,031.25$ & 60.1 \\
Total household income & $17,800,000.00$ & $374,183,060.00$ & $2,338,644.13$ & 100.0 \\
\hline Source: Auth
\end{tabular}

Source: Authors' computation from field data

Note: Income values are in denominated in Nigerian Naira ( 
As shown in Table 2, on the average, men generally earn $23.4 \%$ more than women. This percentage is higher, but, it still points in the same direction with findings by the OECD (2012) report, that women still earn on average 16\% less than men and the difference is even larger among top earners. Oláh, Richter and Kotowska (2014) explained that the female disadvantage is strongly related to their weaker position in the labor market, as women have continued to bear a disproportionately large share of family responsibilities in terms of household work and care, despite their increasing involvement in paid work. In terms of the Naira value of incomes earned, there was an annual average difference of $\$ 224,277.87$, with women in urban areas earning more than those in rural areas. Similarly, men in urban areas also earn more than those in rural areas with an average annual amount of $\$ 171,203.12$. Proportionally, women in rural areas earn approximately $3.4 \%$ less than those in urban areas. While for the men, those in the urban areas earn 3.4\% less than the rural dwellers, even though, the income value earned is higher for those in the urban areas than the rural dwellers. This implies that women with the same level of educational qualifications and skills, usually earn higher in urban areas than in rural areas.

\section{Conclusion}

Residents of Bayelsa State, living either in rural or urban areas are mostly engaged in selfemployment. Comparatively, women are more engaged in self-employment than the men, also, women in urban areas take up more self-employment than women in rural areas. Across Bayelsa State, men generally earn more income than women, be it in the rural or urban areas. Comparatively, women in rural homes earn a lower amount and proportion of the household income than women in urban households, while the men in urban homes earn a higher amount, but a lesser proportion of the household income compared to men in rural areas.

\section{Acknowledgement}

This research was funded by the Tertiary Education Trust Fund (TETFund) of Nigeria through its Institution Based Research (IBR) intervention.

\section{References}

Bayelsa State Government. (2018, November 2). Quick facts. Retrieved November 18, 2018, from Bayelsa State: The Glory of All Lands: http://www.bayelsa.gov.ng/node/42

British Council Nigeria. (2012). 2012 Gender in Nigeria Report 2012: Improving the lives of girls and women in Nigeria (2nd edition ed.). Abuja, Nigeria: British Council Nigeria.

Enfield, S. (2019). Gender roles and inequalities in the Nigerian labour market. Brighton, UK: K4D Helpdesk Report, Institute of Development Studies.

Gayawan, E., \& Adebayo, S. B. (2015). Spatial analysis of women employment status in Nigeria. CBN Journal of Applied Statistics, 6(2), 1-17.

Georgellis, Y., \& Wall, H. J. (2004). Gender Differences in Self-Employment. Federal Reserve Bank of St. Louis Working Paper Series. Working Paper 1999-008C. Retrieved December 30, 2020, from http://research.stlouisfed.org/wp/1999/1999008.pdf 
International Labour Office. (2004). Global employment trends for women 2004. Geneva, Switzerland: International Labour Organization.

International Labour Office. (2018). World employment and social outlook: Trends for women 2018 - Global snapshot. Geneva, Switzerland: International Labour Organization.

Law, T. (2020, January 16). Women are now the majority of the U.S.workforce - But working women still face serious challenges. Time. Retrieved January 3, 2021, from https://time.com/5766787/women-workforce/\%3famp=true

Lundberg, S., Pollak, R. A., \& Stearns, J. (2016). Family inequality: Diverging patterns in marriage, cohabitation, and childbearing. Journal of Economic Perspectives, 30(2), 79-102. doi:http://dx.doi.org/10.1257/jep.30.2.79

OECD. (2012). Closing the gender gap. Paris: OECD Publishing.

OECD. (2016). Gender differences in self-employment rates: in Entrepreneurship at a Glance 2016. Paris: OECD Publishing. doi:https://doi.org/10.1787/entrepreneur_aag2016-29-en

Oláh, L. S., Richter, R., \& Kotowska, I. E. (2014). The new roles of men and women and implications for families and societies. Families and Societies Working Paper Series State-of-the-art report, 11(2014), $59 \mathrm{pp}$.

Olowa, O., \& Adeoti, A. (2014). Effect of education status of women on their labour market participation in rural Nigeria. American Journal of Economics, 4(1), 72-81. doi:10.5923/j.economics.20140401.07

Owutuamor, Z. B. (2018). Roles women play in contributing to household income: A study of homes in Bayelsa State. A Research Project Proposal submitted for TETFund IBR Funding.

Owutuamor, Z. B., Fems, K. M., \& Owutuamor, K. B. (2020). Effects of women's income on the amount of money they contribute to the household in Southern Ijaw Local Government Area of Bayelsa State, Nigeria. Juni Khyat (UGC Care Group I Listed Journal), 10(5-18), 1-11.

Owutuamor, Z. B., Owutuamor, K. B., \& Ukpong, I. G. (2020). Microeconomic analysis of women's contribution in alleviating household poverty in Ekeremor Local Government Area (EKELGA) of Bayelsa State, Nigeria. Juni Khyat (UGC Care Group I Journal) 10(5-17), 10(5:17), 10-18.

Roy, P. K., Haque, S., Jannat, A., Ali, M., \& Khan, M. S. (2017). Contribution of women to household income and decision making in some selected areas of Mymensingh in Bangladesh. Progressive Agriculture, 28(2), 120-129. doi:10.3329/pa.v28i2.33473

UN Women. (2019). Progress of the World's Women 2019-2020: Families in a changing world. UN Women. Retrieved from progress.unwomen.org

World Bank. (2019). Profiting from parity: Unlocking the potential of women's business in Africa. The World Bank Group. Retrieved December 29, 2020, from https://openknowledge.worldbank.org/handle/10986/31421 